\title{
Isolation of Thermophilic Mutants of Bacillus subtilis and Bacillus pumilus and Transformation of the Thermophilic Trait to Mesophilic Strains
}

\author{
By MARY L. DROFFNER AND NOBUTO YAMAMOTO* \\ Department of Microbiology and Immunology, Hahnemann University School of Medicine, \\ Philadelphia, PA 19102, USA
}

(Received 12 December 1984; revised 3 May 1985)

\begin{abstract}
Thermophilic mutants were isolated from mesophilic Bacillus subtilis and Bacillus pumilus by plating large numbers of cells and incubating them for several days at a temperature about $10^{\circ} \mathrm{C}$ above the upper growth temperature limit for the parent mesophiles. Under these conditions we found thermophilic mutant strains that were able to grow at temperatures between $50{ }^{\circ} \mathrm{C}$ and $70^{\circ} \mathrm{C}$ at a frequency of less than $10^{-10}$. The persistence of auxotrophic and antibiotic resistance markers in the thermophilic mutants confirmed their mesophilic origin. Transformation of genetic markers between thermophilic mutants and mesophilic parents was demonstrated at frequencies of $10^{-3}$ to $10^{-2}$ for single markers and about $10^{-7}$ for two unlinked markers. With the same procedure we were able to transfer the thermophilic trait from the mutant strains of Bacillus to the mesophilic parental strains at a frequency of about $10^{-7}$, suggesting that the thermophilic trait is a phenotypic consequence of mutations in two unlinked genes.
\end{abstract}

\section{INTRODUCTION}

Every organism has its own optimal temperature for growth, being either a mesophile, a thermophile or a psychrophile. The factors that dictate the optimum growth temperature have not been established. Identification of genes controlling growth temperatures of these different classes of organisms by genetic means, e.g. transformation, should provide information that will improve our understanding of the mechanisms that determine the range of temperatures over which different organisms can grow. McDonald \& Matney (1963) claimed the transformation of a characteristic which permitted a strain of Bacillus subtilis to grow at temperatures as high as $55^{\circ} \mathrm{C}$ to other $B$. subtilis strains whose upper temperature limit for growth was $50{ }^{\circ} \mathrm{C}$. Furthermore, Friedman \& Mojica (1978) and Lindsay \& Creaser (1975) both claimed transformation of the thermophilic trait from thermophilic 'Bacillus caldolyticus' or Bacillus stearothermophilus to mesophilic B. subtilis. These observations have not been substantiated. The major difficulty in characterizing the thermophilic trait has been a lack of genetic evidence, because the organisms used for these studies were not genetically characterized.

In this communication we report the isolation of thermophilic mutants from two genetically marked mesophilic species (B. subtilis and Bacillus pumilus) and transformation of the thermophilic trait to mesophilic strains. Differences in their gene expression and behaviour over a range of temperatures are discussed.

\section{METHODS}

Bacteria. The B. suhtilis strains used were 168 DB-1 from Dr Roy Doi, University of Texas, Arlington, Tx., USA : $1 \mathrm{~A} 248 \operatorname{trp} \mathrm{C}_{2}^{2} \mathrm{rpoB} 50(0)$, resistant to $50 \mu \mathrm{g}$ rifampicin $\mathrm{ml}^{-1}$. and $1 \mathrm{E} 4(\mathrm{pLSI} 3)$, resistant to $50 \mu \mathrm{g}$ lincomycin $\mathrm{ml}^{-1}$. from the Bacillus Genetic Stock Center, Ohio State University, USA; and 168 BR 151 lys-3 trpC2, requiring lysine and tryptophan. The B. pumilus strains used were $\mathrm{Bp} 203 \mathrm{Arg}^{-}$, requiring arginine, and wild-type $\mathrm{BpB} 1$ from Dr M. Bramucci, Hahnemann University. In addition, Dr F. C. Welder, Pennsylvania State University, College Park, Pa.. USA, supplied us with the thermophile 'B. caldolyticus' YT-P (Heinen \& Heinen, 1972). 
Media. A hard TBAB agar ( $3 \%$, w/v) comprising tryptose blood agar base medium (Difco) plus additional $1.5 \%$ $(\mathrm{w} / \mathrm{v})$ granular agar (Difco) was used throughout for plating at elevated temperatures. L broth, consisting of $5 \mathrm{~g}$ yeast extract (Difco), $10 \mathrm{~g}$ tryptone (Difco) and $5 \mathrm{~g} \mathrm{NaCl}$ per litre, supplemented with $0.02 \mathrm{M}$-sucrose, was used for liquid culture throughout this work. The minimal medium contained $7 \mathrm{~g} \mathrm{~K}_{2} \mathrm{HPO}_{4}, 2 \mathrm{~g} \mathrm{KH}_{2} \mathrm{PO}_{4}, 1 \mathrm{~g}\left(\mathrm{NH}_{4}\right)_{2} \mathrm{SO}_{4}$, $0.1 \mathrm{~g} \mathrm{MgSO}_{+} .7 \mathrm{H}_{2} \mathrm{O}$ and $0.45 \mathrm{~g}$ trisodium citrate dihydrate per litre of distilled water. After autoclaving, $0.02 \mathrm{M}-$ sucrose or $0.1 \%$ glucose was added. For minimal agar plates $3 \%(\mathrm{w} / \mathrm{v})$ granular agar (Difco) was added to the above minimal medium.

Isolation of thermophilic mutants. Either B. subtilis or B. pumilus was grown in approximately $100 \mathrm{ml} \mathrm{L}$ broth to late exponential phase (more than $5 \times 10^{8} \mathrm{cells} \mathrm{m}^{-1}$ ). Bacteria were harvested by centrifugation at $7000 \mathrm{~g}$, washed with $50 \mathrm{ml}$ fresh $\mathrm{L}$ broth, centrifuged again and resuspended in $10 \mathrm{ml} \mathrm{L}$ broth. A small volume (0.1 to $0.3 \mathrm{ml})$ of the concentrated bacterial suspension was spread on TBAB plates. Because of the low frequency at which thermophilic mutants arose it was essential that the total number of bacteria exceeded $10^{9}$ cells per plate and routinely $10-20$ plates were inoculated at a time. The plates were incubated in a closed jar, to prevent excessive evaporation, for 10 or more days at $68^{\circ} \mathrm{C}$.

DNA extraction and preparation of competent recipients for transformation. DNA was extracted by the alkaline procedure of Saito \& Miura (1963). Bacteria were grown in $100 \mathrm{ml} \mathrm{L}$ broth with shaking, centrifuged and resuspended in $10 \mathrm{ml} 0 \cdot 15 \mathrm{M}-\mathrm{NaCl} / 0 \cdot 1 \mathrm{M}$-EDTA, pH 8 . Lysozyme (6 mg; Sigma) was added and the cells were incubated at $37^{\circ} \mathrm{C}$ for $30 \mathrm{~min}$. The lysozyme-treated cells were mixed with $10 \mathrm{ml}$ Tris/SDS $(0 \cdot 1 \mathrm{M}-\mathrm{Tris} / \mathrm{HCl}, 1 \%$ SDS, $0 \cdot 1 \mathrm{M}-\mathrm{NaCl}, \mathrm{pH} 9$ ), quickly frozen in liquid nitrogen and then thawed in a $60^{\circ} \mathrm{C}$ water bath. The freeze-thaw step was repeated and the lysed cells added to an equal volume of distilled phenol saturated with Tris/SDS. The mixture was slowly stirred at $4{ }^{\circ} \mathrm{C}$ for $30 \mathrm{~min}$, centrifuged at $2000 \mathrm{~g}$ for $30 \mathrm{~min}$ and the aqueous phase collected. DNA was precipitated with 2 vols ethanol and isolated by spooling on a glass rod. DNA was resuspended in a small volume (about $0.5 \mathrm{ml})$ of $10 \times$ sodium saline citrate $(\mathrm{SSC})(1 \times \mathrm{SSC}$ is $0.15 \mathrm{M}-\mathrm{NaCl}, 0.015 \mathrm{M}$-trisodium citrate, $\mathrm{pH} \mathrm{7.0}$ ), then 2 to $4 \mathrm{ml} 1 \times \mathrm{SSC}$ was added and the DNA was stored at $4{ }^{\circ} \mathrm{C}$ over a drop of chloroform.

For transformation we used the following procedure, which is adapted from the method of Bott \& Wilson (1967). Bacteria from a single colony were picked off TBAB plates, grown overnight with shaking in $\mathrm{L}$ broth, diluted one to 100 in fresh $\mathrm{L}$ broth and grown for about $3 \mathrm{~h}$ to reach late exponential phase. The cultures were washed twice with, and resuspended in, fresh $\mathrm{L}$ broth. With B. pumilus species competence was dependent on the addition of $\mathrm{CaCl}_{2}$ to a final concentration of $0.03 \mathrm{M}$ (cf. Mandel \& Higa, 1970). For transformation, bacteria were incubated for $1 \mathrm{~h}$ at $37^{\circ} \mathrm{C}$ with a high concentration of DNA $\left(\geq 10 \mu \mathrm{g} \mathrm{ml}^{-1}\right)$ and $0.2 \mathrm{ml}$ samples were plated on TBAB or minimal agar. When selection was made for thermophily, the plates were incubated at $60^{\circ} \mathrm{C}$ or $68^{\circ} \mathrm{C}$ in a closed jar for $48 \mathrm{~h}$; prototrophic transformants were selected on minimal agar plates that were incubated at $37^{\circ} \mathrm{C}$ for $48 \mathrm{~h}$. As a control, DNAase $\left(1 \mathrm{mg} \mathrm{m}^{-1}\right)$ was added to a DNA sample before it was incubated with the competent recipient cells.

\section{RESULTS}

\section{Growth temperature ranges for mesophilic B. subtilis}

Many micro-organisms can grow over a wide range of temperatures. It has been reported that B. subtilis can grow at temperatures between $5^{\circ} \mathrm{C}$ and $55^{\circ} \mathrm{C}$ (Gibson \& Gordon, 1974). However, the upper temperature limit for growth of $B$. subtilis mesophiles was found to be dependent on the kind of medium used. On minimal agar the highest temperature permitting growth of $B$. subtilis was $50{ }^{\circ} \mathrm{C}$. However, addition of $0.1 \%$ Casamino acids to the minimal agar allowed slow growth at a temperature of $56^{\circ} \mathrm{C}$. TBAB supported growth up to an even higher temperature $\left(60^{\circ} \mathrm{C}\right)$. When $B$. subtilis was cultured in L broth with shaking, growth was supported up to $56^{\circ} \mathrm{C}$. Thus it appears that the products of some nutritional biosynthetic genes are temperature-sensitive, although they have yet to be identified.

\section{Isolation and characterization of thermophilic mutants of $B$. subtilis}

From the results described above, a temperature of $68^{\circ} \mathrm{C}$, which is about $10{ }^{\circ} \mathrm{C}$ above the upper limit for growth of $B$. subtilis on a rich agar medium, was chosen for selection of thermophilic mutants. Using TBAB plates we first isolated thermophilic mutants from $B$. subtilis 168 strains DB-1 and BR151 at a frequency of less than $10^{-10}$ (Table 1). All of the thermophilic $B$. subtilis mutants that were isolated were designated $\mathrm{T} / \mathrm{r}$ and grew at temperatures between $50{ }^{\circ} \mathrm{C}$ and $70^{\circ} \mathrm{C}$, but were no longer able to grow at temperatures below $50{ }^{\circ} \mathrm{C}$. However, the thermophilic mutants of $B$. subtilis BR 151 retained their requirements for lysine and tryptophan at $50{ }^{\circ} \mathrm{C}$ (Table 1). These amino acid requirements could not be demonstrated above $55^{\circ} \mathrm{C}$ because the organisms grow only on rich nutrient media under these conditions. 
Nevertheless, the demonstration that the auxotrophic requirements of the parent strain were retained unequivocally confirmed that these thermophilic mutants were derivatives of $B$. subtilis strains.

\section{Transformation of the thermophilic trait $(T / r)$ from the mutant thermophilic $B$. subtilis to mesophilic B. subtilis strains}

Prototrophic markers $\left(l y s^{+}\right.$or $\left.t r p^{+}\right)$were transferred from thermophilic $B$. subtilis DB-1 T/r to the mesophilic recipient $B$. subtilis $\mathrm{BR} 151$ by transformation at a frequency of $10^{-3}$ to $10^{-2}$ (Table 2), which is similar to the frequency observed for the transfer of prototrophic markers between two mesophilic strains (cross 2, Table 2). This efficient transformation also supports the idea that these $B$. subtilis thermophilic mutants are derived from mesophilic $B$. subtilis strains.

We were also able to transfer the thermophilic trait from $B$. subtilis thermophiles to $B$. subtilis mesophiles. In a cross between thermophilic strain DB-1 T/r and mesophilic BR 151 , transfer of both the thermophilic trait and prototrophic markers was scored (cross 1, Table 2). The transformation frequency of the thermophilic trait was about $10^{-7}$ while the transformation frequency of prototrophic markers was $10^{-3}$ to $10^{-2}$ for a single marker and about $10^{-7}$ for the cotransfer of two unlinked prototrophic markers $\left(l y s^{+}\right.$and $t r p^{+}$) (see Table 2). Similar data were obtained with five $B$. subtilis $\mathrm{T} / \mathrm{r}$ mutant isolates. Since the transformation frequency of the thermophilic trait is similar to that found for transformation of two unlinked genes, it can be suggested that mutations in two unlinked genes are sufficient to cause thermophily in $B$. subtilis.

When we attempted to transform $B$. subtilis BR151 with DNA isolated from an existing thermophilic species, ' $B$. caldolyticus' YT-P, however, the frequency of transformation between these two strains was about 400 - to 1000 -fold lower than the frequency observed between the $B$. subtilis thermophilic mutants and their parental strains. The low frequency of transformation between ' $B$. caldolyticus' and $B$. subtilis may be explained by the differences in their base compositions: the mol $\% \mathrm{GC}$ of 'B. caldolyticus' is in the region 62 to 65 (Sharp, 1982) while that of $B$. subtilis is 42 to 48 (Normore, 1976).

Viability and stability of thermophilic mutants

All the thermophilic mutants and transformants that were isolated were found to be unstable. The thermophilic $B$. subtilis strains grew within a rather confined temperature range of $50{ }^{\circ} \mathrm{C}$ to $70{ }^{\circ} \mathrm{C}$. The mutants were unable to survive above $71^{\circ} \mathrm{C}$ or below $49^{\circ} \mathrm{C}$. When thermophilic strains were incubated at $47^{\circ} \mathrm{C}$ the c.f.u. remained about the same for approximately $2 \mathrm{~h}$, but dropped more than 1000 -fold during the next $6 \mathrm{~h}$. Incubation at $72{ }^{\circ} \mathrm{C}$ caused a decrease in c.f.u. by 10 -fold after $1 \mathrm{~h}$ and about $10^{5}$-fold after $6 \mathrm{~h}$. However, the thermophilic $B$. subtilis strains remained viable during storage at $-50{ }^{\circ} \mathrm{C}$ for at least 1 year. The basis of the instability of the thermophilic mutants remains to be studied.

\section{Expression of antibiotic resistance markers in thermophilic B. subtilis transformants}

Thermophilic transformants of mesophilic $B$. subtilis carrying antibiotic resistance markers were tested for antibiotic sensitivity at the upper and lower thermophilic temperature range. Rifampicin resistance was expressed in T/r transformants of B. subtilis $1 \mathrm{~A} 248$ at both $50{ }^{\circ} \mathrm{C}$ and $68^{\circ} \mathrm{C}$, showing that the mesophilic parental gene is present and expressed when bacteria are incubated over the entire thermophilic temperature range. The thermophilic $(\mathrm{T} / \mathrm{r})$ transformants of $B$. subtilis $1 \mathrm{E} 4$ containing the $\mathrm{Lm}^{\mathrm{r}}$ plasmid (pLS13), however, expressed lincomycin resistance at the lower temperature range $\left(50{ }^{\circ} \mathrm{C}-55^{\circ} \mathrm{C}\right.$ ) but not at the higher temperature range $\left(65^{\circ} \mathrm{C}-68^{\circ} \mathrm{C}\right)$. Clones isolated from $\mathrm{T} / \mathrm{r}$ transformants grown at $65^{\circ} \mathrm{C}$ were no longer able to express lincomycin resistance at $50{ }^{\circ} \mathrm{C}$. This observation suggests that the elevated temperature results in the curing of the $\mathrm{Lm}^{\mathrm{r}}$ plasmid (pLS13) from $1 \mathrm{E} 4$ transformants.

\section{Thermophilic mutants of $B$. pumilus}

Studies on the production of thermophilic mutants and transformation of the thermophilic trait were extended to another Bacillus species, namely $B$. pumilus. Unlike B. subtilis, nutritional enrichment does not expand the upper temperature range for growth of $B$. pumilus above $50^{\circ} \mathrm{C}$. 

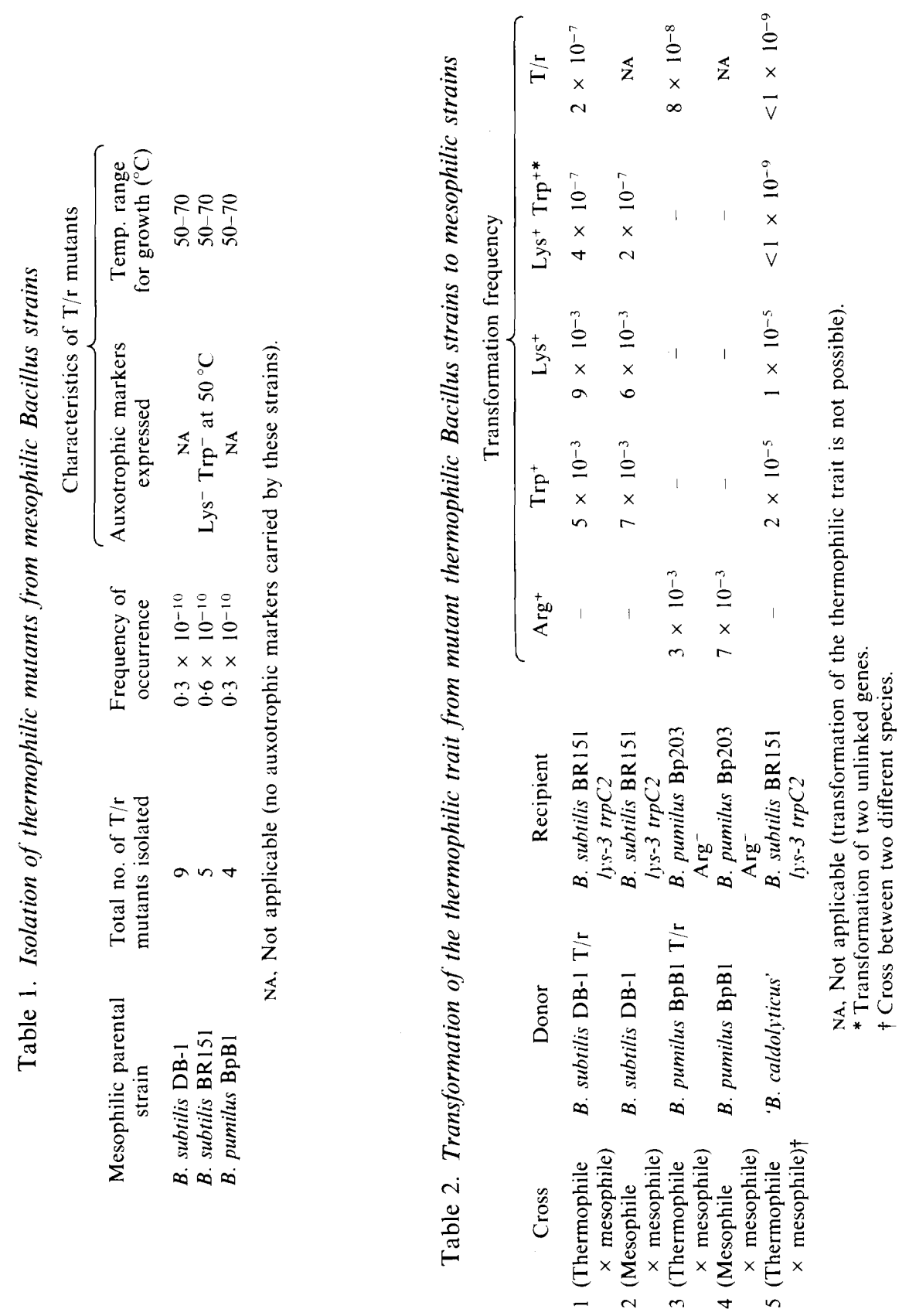
We isolated thermophilic mutants of $B$.pumilus at a frequency of less than $10^{-10}$ (Table 1). These thermophilic mutants grew at temperatures above $50^{\circ} \mathrm{C}$ and required rich medium at the higher thermophilic temperature range $\left(55^{\circ} \mathrm{C}-70{ }^{\circ} \mathrm{C}\right)$. Transformation of the thermophilic trait to mesophilic $B$. pumilus, made competent by incubation in the presence of $\mathrm{CaCl}_{2}$, occurred at a frequency of about $10^{-7}$, while transfer of a single prototrophic marker between these mesophilic and thermophilic $B$. pumilus strains occurred at a frequency of about $10^{-3}$ to $10^{-2}$ (Table 2). These data are similar to those obtained with $B$. subtilis and support the hypothesis that mutations in two genes are involved in the acquisition of thermophily.

\section{DISCUSSION}

The upper temperature range for growth of both mesophiles and thermophiles of $B$. subtilis and thermophiles of $B$. pumilus was increased by growing on rich media; this is consistent with the findings of Baker et al. (1953). Thus it appears that the products of some nutritional genes are temperature-sensitive. It has not, therefore, been possible to demonstrate the presence of auxotrophic markers in strains growing at the upper part of their thermophilic temperature range. Moreover, Gray \& Jackson (1973) reported that with mesophilic mutants obtained from the psychrophile, Micrococcus cryophilus, the phenotype associated with some of the parental markers cannot be demonstrated at mesophilic temperatures because of nutrient requirements.

The genetics of thermophilic growth is a controversial subject. Johnson (1979) suggested that difficulties of studies of thermophiles is mainly due to the lack of established methods for isolating thermophilic mutants and the unavailability of previously isolated thermophilic mutants for genetic studies on the thermophilic trait. Confirmation of some of the previous reports, for example transformation of the thermophilic trait to mesophiles (Friedman \& Mojica, 1978; Lindsay \& Creaser, 1975), has been hampered by the unavailability of thermophilic derivative strains. The present paper explains that such thermophilic strains may be easily lost due to their instability. However, we found that viability was maintained for a long period of time during storage of the thermophilic mutants at $-50^{\circ} \mathrm{C}$. With this knowledge we have now been able to establish a method that permits genetically marked strains of boih $B$. subtilis and $B$. pumilus to mutate to form thermophilic strains which grow at temperatures from $50{ }^{\circ} \mathrm{C}$ to $70{ }^{\circ} \mathrm{C}$. Our hypothesis that mutations in two genes are responsible for the thermophilic nature of our mutants is consistent with the low frequencies of mutation to thermophilic growth and the observed frequency of transformation of the thermophilic trait to mesophiles.

This investigation was supported by the US Army Medical Research and Development Command grant no. DAMD 17-83-G-9562 to N.Y.

\section{REFERENCES}

Baker, H., Sobotka, H. \& Hunter, S. H. (1953). Growth requirements of some thermophilic and mesophilic bacilli. Journal of General Microbiology 9. 485-493.

BotT, K. F. \& Wilson, G. A. (1967). Development of competence in the Bacillus subtilis transformation system. Journal of Bacteriology 94, 562-570.

Friedman, S. M. \& MoJica, T. (1978). Transformants of Bacillus subtilis capable of growth at elevated temperatures. In Biochemistry of Thermophily, pp. 117-126. Edited by S. M. Friedman. New York: Academic Press.

Gibson, T. \& Gordon, R. E. (1974). Endosporeforming rods and cocci. In Bergey's Manual of Determinative Bacteriology, 8th edn, pp. 529-550. Edited by R. E. Buchanan \& N. E. Gibbons. Baltimore: Williams \& Wilkins.
Gray, R. J. H. \& JACKSON, H. (1973). Growth and macromolecular composition of a psychrophile, Micrococcus cryophilus, at elevated temperatures. Antonie ran Leeuwenhoek 39, 497-504.

Heinen, U. J. \& Heinen, W. (1972). Characteristics and properties of a caldo-active bacterium producing extracellular enzymes and two related strains. Archiv für Mikrobiologic' 82, 1-23.

Johnson, E. J. (1979). Thermophile genetics and the genetic determinants of thermophily. In Strategies of Microbial Life in Extreme Entironments, pp. 471 487. Edited by M. Shilo. Weinheim: Verlag Chemie.

Lindsay, J. \& Creaser, E. R. (1975). Enzyme thermostability is a transformable property between Bacillus species. Nature, London 235, 650652. 
McDonald, W. C. \& Matney, T. S. (1963). Genetic transfer of the ability to grow at $55^{\circ} \mathrm{C}$ in Bacillus subtilis. Journal of Bacteriology 85, 218-220.

Mandel, M. \& Higa, A. A. (1970). Calcium-dependent bacteriophage infection. Journal of Molecular Biology 53, 159-162.

NORMORE, W. M. (1976). Guanine-plus-cytosine (GC) composition of the DNA of bacteria, fungi, algae and protozoa. In Handbook of Biochemistry and
Molecular Biology, 3rd edn, vol. II, p. 85. Edited by G. D. Fasman. Cleveland, Ohio: CRC Press.

SaITo, H. \& MiURA, K. I. (1963). Preparation of transforming deoxyribonucleic acid by phenol treatment. Biochimica et biophysica acta 72, 619-629.

SHARP, R. J. (1982). Taxonomic and genetic studies of Bacillus thermophilus. PhD thesis, Trent Polytechnic, UK. 